In Rozenblat C., Pumain D., Velasquez E. (eds.) (2018). International and Transnational Perspectives on Urban Systems, UN-Habitat / Springer Series "Advances in Geographical and Environmental Sciences", DOI: $\underline{10.1007 / 978-981-10-7799-9}$

\title{
Chapter 2: Urban systems between national and global: recent reconfiguration through transnational networks
}

Celine ROZENBLAT*, University of Lausanne, Institute of Geography and Sustainability, Lausanne, Switzerland, Celine.rozenblat@unil.ch

*Corresponding author

\begin{abstract}
Because the whole book's issue assumes the uneven integrations of national/continental urban systems inside the global economy, this chapter evaluates the rates and qualitative modes of integration of the national urban systems by the economic networks that are dominated by multinational firms. The empirical study encompasses the largest 1,250 cities of the World delineated in a comparative way according to common definitions of Large Urban Regions (LUR). The position of LURs in multinational firms' ownership networks in two years, 2010 and 2013, correspond to the deepest period of the crisis and the following recovery, respectively. Thus, we checked that the fast reorganization of multinational firms facing this crisis between 2010 and 2013 did not fundamentally transform their strong urban organization but rather introduced some minor changes, particularly due to the simultaneous breakthrough of emergent countries' companies (especially the Chinese ones). Synthetic network clustering methods partitioning cities of the world, offer clear visions of the structure of the multipolar urban networks. They reveal "regions" of integration of cities for all kinds of multinational companies but also distinguishing companies' according to their skill levels either in Industry or in Services. A special attention is given to some highly integrated cities appearing with properties of "City-States" i.e. without a strong national urban system.
\end{abstract}

Keywords: Networks of cities; Globalization; Multinational firms; Clustering methods; multipolar system.

\section{Introduction}

Before analyzing the evolution of national or continental urban systems in detail, we propose an insight into the complexity of inter-urban interactions: how cities unevenly support national and transnational processes of globalization and are, in turn, transformed by these networks. This specific urban view brings original information beyond the basic international game between countries (Storper, 1997; Scott, 2012). The acceleration of globalization trends since the end of the Second World War has, with different speeds, rates and qualitative modes, affected national urban systems that were previously strengthened through the constitution of nation states during the $19^{\text {th }}$ and $20^{\text {th }}$ centuries.

Cities' linkages within the global networks of multinational firms are significant aspects of these global processes because they transgress the boundaries of longstanding solidarities formerly installed inside the boundaries of nation-states. We use an original database at a global scale to measure the extent to which the financial linkages deployed within and between cities among the subsidiaries owned by multinational firms, have created new 
patterns in the organization of systems of cities ${ }^{1}$. Are transnational linkages establishing new sources of interdependencies that would substitute for the longstanding co-evolution in national urban systems? Does this globalization process affect cities equally? Do multinational firms adapt to the existing structure of national urban systems, or are they more selective? If the latter is the case, do they structure new cities' networks and at what scale, intra-nationally or across countries?

Multinational firm networks are recognized as the main drivers of economic globalization. They have exploded over the last four decades, but they have also been affected by the deep financial crisis of 2008. To discuss their long-term interaction with cities and their shorter-term interactions, i.e., the effects of the global crisis on levels of urban system integration, this chapter examines the position of cities in these networks in two years, 2010 and 2013, which correspond to the deepest period of the crisis and the following recovery, respectively. The long- and short-term dynamics of cities' globalization requires distinguishing the structural aspects from the conjectural variations. Thus, we checked that the fast re-organization of multinational firms facing this crisis between 2010 and 2013 did not fundamentally transform their strong urban organization but rather introduced some minor changes, particularly due to the simultaneous breakthrough of emergent countries' companies (especially the Chinese ones).

The interactions between multinational firms, cities and states respective developments are a critical polemic issue. Globalization has been seen by a majority of influential scientists for more than twenty-five years as a game that involves a limited number of "global cities" while ignoring national borders (Sassen, 1991; Taylor, 2001; Taylor et al., 2003, 2015). However, other approaches of "nested cities" (Hill, Fujita, 2003; Rozenblat, 2004) contest this restricted vision and argue that national structures still impose heavy constraints on cities' characteristics and dynamics. However, the latter view does not deny the globalization processes, and the former has numerous nuanced arguments.

For instance, Sassen $(2007,2010)$ emphasizes that globalization is so much embedded inside the national institutions that it reshapes them: "Multiple national conditions and dynamics are likely to be engaged by the global and often are the global, but function inside the national" (Sassen, 2010, p.2). In fact, the limits between national and international become increasingly fuzzy such that national and local governments' and private actors' actions address international issues. Although some cities seem to abstract from their national urban systems, the urban policies are still limited by the national institutional environment, which determines a large part of the general growth and, thus, the possible gains through agglomeration economies (Polese, 2005). Local public actions are intrinsically linked to national environments, which are composed by culture, values and trust (Fukayama, 1995; Landis \& Zhang, 1998) that determine the scope of the role of institutions (Acemoglu et al., 2001; Easterly \& Levine, 2001). These institutions are themselves not fixed: they evolve according to internal dynamics that are influenced by media, business, finance and intellectuals extending cultural and political globalization (Short \& Kim, 1999).

\footnotetext{
${ }^{1}$ The empirical study of cities' globalization is based on a large database that we update regularly, encompassing the direct or indirect ownership networks of the 3,000 main groups of the world (approximately 800,000 enterprises linked by 1 million financial linkages at each date and positioned in comparative urban areas [see (2) below for more precision]) (source: Bureau Van Dijk, 2010, 2013).
} 
These transformations of national urban structures under the influence of feedback loops within globalization processes are among the core issues of this book. We assume that the degree of globalization's influence on the transformation of the national urban structure varies widely throughout the world. The intermediary levels that are created between the national and the global, i.e., free trade zones and international agreements, integrate cities within dynamics that overpass national borders but do so in combination with national or regional path-dependent specificities that impose a reciprocal adaptation.

\section{Measuring the position of cities within global networks}

Studying inter-city networks helps reveal the mutual interdependencies between cities' trajectories but requires caution in the data construction, analysis and visualization methods.

\subsection{Evaluating the inter-cities networks through multinational firms' ownership linkages}

Empirical measurements of urban connectivity are generally developed on the basis of samples of multinational firm networks that are summed to assess the weight of cities (the nodes of this graph) and links between cities (edges of the graph) (Pred, 1977; Cohen, 1981; Rozenblat \& Pumain, 1993, 2007). Multinational firms deploy networks of two different natures: on the one hand, networks that are internal to the company are created through the multiplication of subsidiaries or joint ventures in different countries within the same group; on the other hand, external networks of subcontracting, alliances and coordination are developed with other companies. Internal business networks are more stable and dense in terms of interactions than external networks: it is through internal networks that most of the capital, know-how and technological or managerial innovations are spread (Walter et al., 2007).

Thus, to base the evaluation of cities' interactions on strong and stable networks, we use firms' ownership networks (internal networks) that represent the "observed" financial links between companies and creating "quasi-trees" made up of chains of filiations, as adopted by other authors (Alderson \& Beckfield, 2004; Wall, 2009). We built a large database of all direct and indirect links of financial ownership developed directly or indirectly by the top 3,000 worldwide companies according to their turnover in 2009 (for 2010) and in 2012 (for 2013) based on the best possible source of information (ORBIS, Bureau van Dijk, 2010, 2013) ${ }^{2}$. The University of Lausanne and the European Research Council (ERC) Grant GeodiverCity completed it especially for the locations and activities of firms. The two teams developed deep work on the geographical aggregation of firms by "Large Urban Regions" (LURs) at the world scale, corresponding to extended functional urban regions (Rozenblat et al., 2017), which allows us to compare cities with similar delineations throughout the world. We refer to them as LURs or cities, interchangeably ${ }^{3}$.

\footnotetext{
${ }^{2}$ This database encompasses about 700,00 subsidiaries in 2010 and 800,000 subsidiaries in 2013, linked by 1 million filiation links in 2010 and 1.2 million in 2013. The 3,000 first firms are different in 2010 and in 2013, only maintaining a common part, for which the network of subsidiaries could change. Through these independent data, we can evaluate the main strength of the global networks at each date, considering the transformations of the dominant economic actors.

${ }^{3}$ This preparation needs some huge efforts and a high-level expertise for each country to evaluate the relevance of the LURs' delineations.
} 
In order to shift from these individual firms' networks towards cities' networks, and as the exact proportion of owned capital is not always given with enough precision, we measured the intensity of a city relationship with any other city by adding the total number of financial relations of the firms located in the couple of LURs: $L O_{i j}$ is the number of subsidiaries located in the city $j$ having their headquarters (or a minority shareholder) in the city $i$. All the oriented linkages $l_{i j}^{e}$ of the enterprises $e$ having a shareholder or an headquarters in city $i$ and a subsidiary located in city $j$, count for 1 and are summed up to obtain $L O_{i j}$ :

$$
L O_{i j}=\sum_{e=1}^{p} l_{i j}^{e}
$$

Note that the city $j$ can also have enterprises $f$ hosting shareholders who invest in subsidiaries of the city $i$. Then the non-oriented link $L N O_{i j}$ between cities $i$ and $j$ is expressed as follows:

$$
L N O_{i j}=\sum_{e=1}^{p} l_{i j}^{e}+\sum_{f=1}^{q} l_{j i}^{f}
$$

In the empirical following study, we will specify when we will use oriented or nonoriented linkages.

The total weight of each city in the network can be revealed by two different values:

- $\quad H_{i}$; the number of controls from headquarters of $i$ to other cities $j$ is evaluated by the number of outgoing ownership linkages from the city $i$ towards all other cities $j$;

- $\quad S_{j}$ : the number of links of subsidiarity of $j$ from all other cities $i$ is measured by the number of ingoing linkages of the city $j$ from all the other cities $i$ (as these linkages are oriented from the headquarters' LUR $i$ to the subsidiaries of the LUR $j, H_{i}$ is different from $S_{i}$ ).

$H_{i}$ and $S_{j}$ are computed as expressed in equations (3) and (4):

$H_{i}=\sum_{j=1}^{k} L O_{i j}$

$S_{j}=\sum_{i=1}^{l} L O_{i j}$

In the network analysis, the value of $H_{i}$ is also called the city's "Weighted Out-Degree" (here representing the power of subsidiaries' control that is concentrated in the city $i$ on subsidiaries outside the city $i$ ) and the value $S_{j}$ is the city's "Weighted In-Degree" (the attractiveness of the city $j$ for subsidiaries controlled from outside the city $j$ ).

Our method for measuring interurban linkages through multinational firm ownership is rather different from the approach widely spread out by the GaWC group (Globalization and World Cities group, Loughborough University). The GaWC developed a popular approach for advanced business service firms (Taylor, 2001). However, their method consists of building hypothetical networks from the information about the location of firms: they connect all firms belonging to the same group by all possible links, which creates "complete graphs" (graphs connecting all the units of each group). This construction tends to amplify the centrality attributed to the largest cities (Neal, 2012). Because of this bias and because of their significance, we prefer to consider "real" linkages 
that are observed and measured by the financial ownership linkages between firms.

\subsection{The core of the worldwide complex network of cities}

The worldwide urban system of multinational firms' ownership networks appears as a very complex system in 2010 and in 2013. We registered 1,206 LURs deploying a total of 37,116 oriented and weighted linkages with other LURSs in 2010 (for about 900.000 firms' linkages) and 1,253 LURs with 40,685 oriented and weighted linkages in 2013 (for about 1 million firms' linkages). To identify the core of this worldwide urban system and avoid considering anecdotic linkages, we selected the main LURs in this network to make the Figure 1 (i.e., cities having more than 50 control and subsidiary linkages). We also selected the largest number of oriented linkages with a minimum threshold of 10 firms' links between cities from the headquarters to the subsidiaries. The resulting simplified network includes 631 cities in 2010 (5,776 linkages) and 718 cities in 2013 (6,398 linkages) (Fig.1). On this graph, we positioned cities according to the intensity of their reciprocal linkages but not according to their location: the closer they are, the more linkages with their neighbors they will have in the network.

Regardless of the chosen years, i.e., 2010 or 2013, the main pattern of the network is composed of one single component, which means that cities form a unique network in which all cities are connected. Another interesting feature is that inside this global network, more compact clusters of highly connected cities emerge, which correspond to cities that are on the same continents (illustrated by the color of the cities and their linkages on figure 1). We may thus conclude that "space matters" in the economy (indeed, physical and cultural proximity) and that the "first law of geography" (Tobler, 1972) still operates as a constraint on the strategies of global firms when they choose their urban locations (Rozenblat, 2015). 
Figure 1: Major Urban Network of multinational firms' ownership linkages (2010-2013)

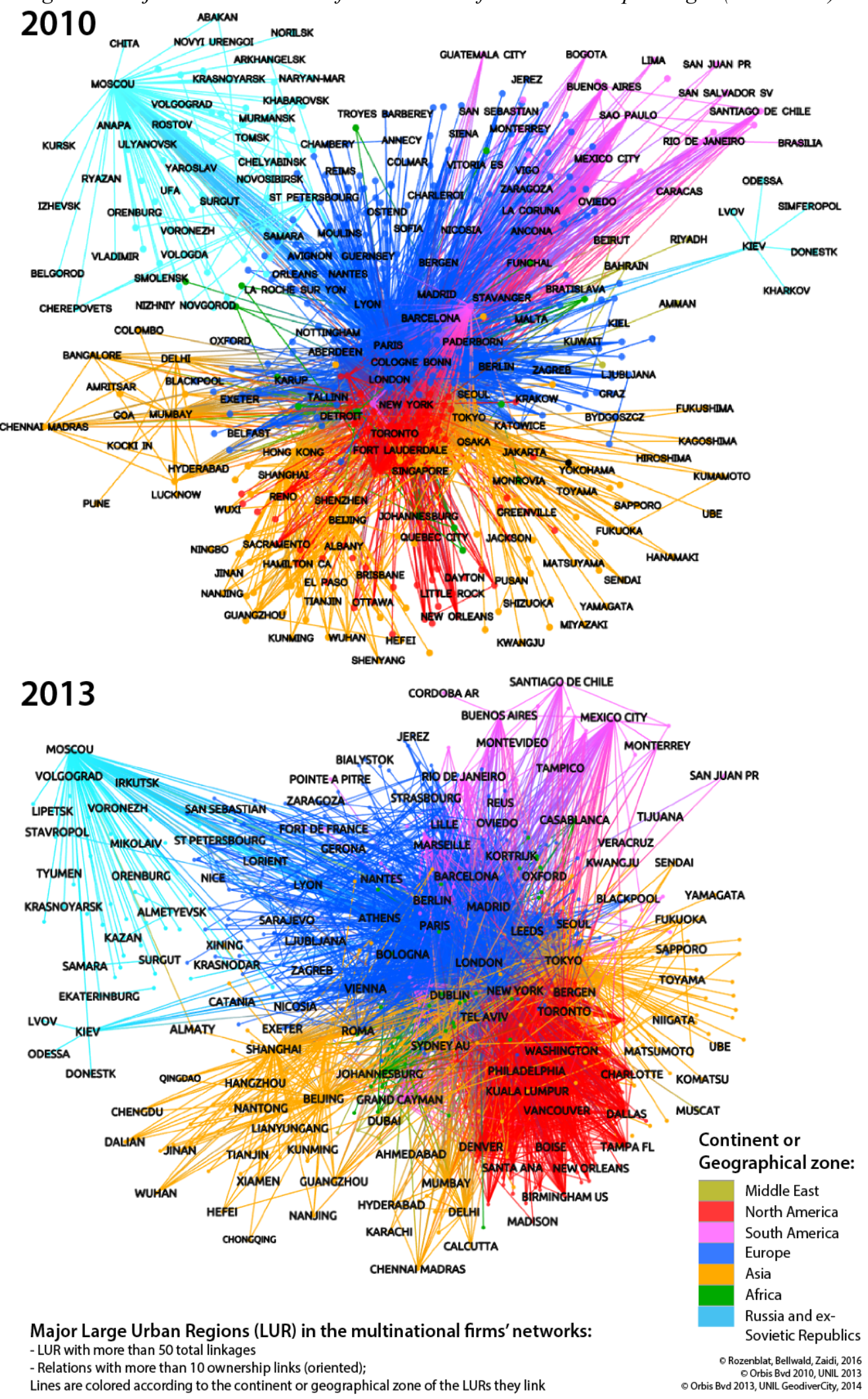


European and North American cities are at the core of the network. The two clusters remain rather isolated from each other, thus confirming high continental cohesion. On these two continents, London, Paris and New York are the main centers of the network. They polarize the larger part of the worldwide cities' network, and London is at the interface between the two continents.

Cities from other continents are connected to these two central clusters. Asian and Oceania cities (in orange) are divided into two main parts: on the one side, Japanese cities, which started their integration with globalization in the 1970s, including Tokyo, are strongly connected with London and New York. On the other side, Chinese and Indian cities entered the globalization process later (starting in the 1990s). Here, Hong-Kong, Beijing, Shanghai, and Shenzhen drive the integration of other Chinese cities (as soon as in 2010), as Mumbai and Delhi do for Indian cities. Moscow polarizes another cluster forming an isolated system of the ex-Soviet Republics. Other South American, Middle East and African cities are spread throughout the network among European or North American cities.

The network did not change much between 2010 and 2013, which confirms a very stable structure of the cities' network, although the two samples of firms are not completely similar. The main change between 2010 and 2013 is the increasing size of the network accompanied by the slight growth of its complexity. Indeed, the density of the total network of cities evolved from an average of 30 links per city in 2010 to 32 in $2013^{4}$. It means that a process of diffusion of the integration of globalization among new cities with a densification of linkages between cities that were already in the network.

Among the new cities appearing in 2013, the most are from South America. They are preferentially linked to Spanish and Portuguese cities, due to their linguistic proximity. In addition, Asian cities, particularly Chinese cities, have become more numerous.

In summary, the two consecutive patterns of 2010 and 2013 outline two main features that are further developed below:

- There is a stable high cohesion between cities by continental and national zones at both dates.

- Between the dates, the networks seem to become less centralized in the main core cities of the network.

\subsection{National and continental scales of cities' insertion into worldwide networks}

In absolute terms, the global number of all registered linkages of multinational firms increased between 2010 and 2013, but the linkages grew at unequal speeds according to the various geographical scopes (Tab.1).

\footnotetext{
${ }^{4}$ These calculations are based on the total initial number of cities and all their weighted linkages.
} 
Table 1: Scope of multinational firms' linkages by continents and selected countries (2010-2013)

\begin{tabular}{|c|c|c|c|c|c|c|c|c|c|}
\hline \multirow[t]{2}{*}{2010} & \multicolumn{9}{|c|}{ Scope of multinational firms' linkages } \\
\hline & $\begin{array}{l}\text { intra- } \\
\text { urban } \\
\text { number }\end{array}$ & $\begin{array}{l}\text { Intra- } \\
\text { national } \\
\text { number }\end{array}$ & $\begin{array}{l}\text { Intra- } \\
\text { continental } \\
\text { number }\end{array}$ & $\begin{array}{l}\text { Inter- } \\
\text { continental } \\
\text { number }\end{array}$ & $\begin{array}{l}\text { TOTAL } \\
\text { number }\end{array}$ & $\begin{array}{l}\text { intra- } \\
\text { urban } \\
\% \text { row }\end{array}$ & $\begin{array}{l}\text { Intra- } \\
\text { national } \\
\% \text { row }\end{array}$ & $\begin{array}{l}\text { Intra- } \\
\text { continental } \\
\% \text { row }\end{array}$ & $\begin{array}{l}\text { Inter- } \\
\text { continental } \\
\% \text { row }\end{array}$ \\
\hline TOTAL & 277492 & 663457 & 809081 & 394628 & 1006412 & 27.6 & 65.9 & 80.4 & 19.6 \\
\hline \multicolumn{10}{|l|}{ Continents } \\
\hline Africa & 652 & 2704 & 3039 & 9369 & 12408 & 5.3 & 21.8 & 24.5 & 75.5 \\
\hline Asia and Oceania & 31132 & 87940 & 99714 & 73304 & 173018 & 18.0 & 50.8 & 57.6 & 42.4 \\
\hline Europe & 221627 & 402766 & 519818 & 141584 & 661402 & 33.5 & 60.9 & 78.6 & 21.4 \\
\hline South America & 2721 & 5729 & 8438 & 48026 & 56464 & 4.8 & 10.1 & 14.9 & 85.1 \\
\hline North America & 20224 & 162795 & 176079 & 119048 & 295127 & 6.9 & 55.2 & 59.7 & 40.3 \\
\hline Middle East & 1136 & 1523 & 1993 & 2551 & 4544 & 25.0 & 33.5 & 43.9 & 56.1 \\
\hline \multicolumn{10}{|l|}{ Countries } \\
\hline China & 3731 & 8951 & 11757 & 18064 & 29821 & 12.5 & 30.0 & 39.4 & 60.6 \\
\hline Brazil & 461 & 1390 & 1751 & 5376 & 7127 & 6.5 & 19.5 & 24.6 & 75.4 \\
\hline Russia & 20002 & 48357 & 52450 & 989 & 53439 & 37.4 & 90.5 & 98.1 & 1.9 \\
\hline India & 2095 & 4656 & 5424 & 5848 & 11272 & 18.6 & 41.3 & 48.1 & 51.9 \\
\hline South Africa & 191 & 1724 & 1955 & 3106 & 5061 & 3.8 & 34.1 & 38.6 & 61.4 \\
\hline USA & 17087 & 147246 & 160517 & 109155 & 269672 & 6.3 & 54.6 & 59.5 & 40.5 \\
\hline Japan & 14805 & 34736 & 38260 & 18416 & 56676 & 26.1 & 61.3 & 67.5 & 32.5 \\
\hline Great Britain & 88926 & 122926 & 157128 & 43607 & 200735 & 44.3 & 61.2 & 78.3 & 21.7 \\
\hline Germany & 25123 & 46257 & 73393 & 14769 & 88162 & 28.5 & 52.5 & 83.2 & 16.8 \\
\hline France & 25027 & 58625 & 89262 & 23220 & 112482 & 22.2 & 52.1 & 79.4 & 20.6 \\
\hline
\end{tabular}

\begin{tabular}{|c|c|c|c|c|c|c|c|c|c|}
\hline \multirow[t]{2}{*}{2013} & \multicolumn{9}{|c|}{ Scope of multinational firms' linkages } \\
\hline & $\begin{array}{l}\text { intra- } \\
\text { urban } \\
\text { number }\end{array}$ & $\begin{array}{l}\text { Intra- } \\
\text { national } \\
\text { number }\end{array}$ & $\begin{array}{l}\text { Intra- } \\
\text { continental } \\
\text { number }\end{array}$ & $\begin{array}{l}\text { Inter- } \\
\text { continental } \\
\text { number }\end{array}$ & $\begin{array}{l}\text { TOTAL } \\
\text { number }\end{array}$ & $\begin{array}{l}\text { intra- } \\
\text { urban } \\
\%\end{array}$ & $\begin{array}{l}\text { Intra- } \\
\text { national } \\
\%\end{array}$ & $\begin{array}{l}\text { Intra- } \\
\text { continental } \\
\%\end{array}$ & $\begin{array}{l}\text { Inter- } \\
\text { continental } \\
\%\end{array}$ \\
\hline TOTAL & 304759 & 754398 & 931655 & 264342 & 1195997 & 25.5 & 63.1 & 77.9 & 22.1 \\
\hline \multicolumn{10}{|l|}{ Continents } \\
\hline Africa & 2236 & 6498 & 7453 & 16284 & 23737 & 9.4 & 27.4 & 31.4 & 68.6 \\
\hline Asia and Oceania & 34658 & 123651 & 144658 & 111854 & 256512 & 13.5 & 48.2 & 56.4 & 43.6 \\
\hline Europe & 232881 & 417249 & 552247 & 177610 & 729857 & 31.9 & 57.2 & 75.7 & 24.3 \\
\hline South America & 5442 & 9598 & 14894 & 65673 & 80567 & 6.8 & 11.9 & 18.5 & 81.5 \\
\hline North America & 28594 & 195382 & 209929 & 155033 & 364962 & 7.8 & 53.5 & 57.5 & 42.5 \\
\hline Middle East & 954 & 2008 & 2462 & 4562 & 7024 & 13.6 & 28.6 & 35.1 & 64.9 \\
\hline \multicolumn{10}{|l|}{ Countries } \\
\hline China & 5691 & 26187 & 30346 & 25313 & 55659 & 10.2 & 47.0 & 54.5 & 45.5 \\
\hline Brazil & 1051 & 3072 & 3688 & 8303 & 11991 & 8.8 & 25.6 & 30.8 & 69.2 \\
\hline Russia & 11828 & 30944 & 36501 & 1701 & 38202 & 31.0 & 81.0 & 95.5 & 4.5 \\
\hline India & 2424 & 7496 & 8902 & 9258 & 18160 & 13.3 & 41.3 & 49.0 & 51.0 \\
\hline South Africa & 1410 & 4815 & 5527 & 5082 & 10609 & 13.3 & 45.4 & 52.1 & 47.9 \\
\hline USA & 25355 & 185099 & 199646 & 144134 & 343780 & 7.4 & 53.8 & 58.1 & 41.9 \\
\hline Japan & 13072 & 37258 & 43371 & 24255 & 67626 & 19.3 & 55.1 & 64.1 & 35.9 \\
\hline Great Britain & 71471 & 97867 & 134817 & 52307 & 187124 & 38.2 & 52.3 & 72.0 & 28.0 \\
\hline Germany & 31774 & 56833 & 89567 & 18827 & 108394 & 29.3 & 52.4 & 82.6 & 17.4 \\
\hline France & 31348 & 61659 & 93303 & 25223 & 118526 & 26.4 & 52.0 & 78.7 & 21.3 \\
\hline
\end{tabular}

Source: ORBIS - BvD, 2010, 2013, UNIL-IGD, GeodiverCity

The intercontinental linkages had slow growth $(20 \%$ in $2010,22 \%$ in 2013$)$, which undoubtedly reflects a long-term progressive increase of the proportion of intercontinental linkages, which have roughly kept the same speed as the previous period (18\% in 2006) (Rozenblat, 2010). Conversely, intra-continental and national linkages decreased in proportion. The intra-urban linkages (when owners and subsidiaries are located in the same Large Urban Region), despite absolute growth, decreased in proportion (from $27.6 \%$ to $25.5 \%)$. 
However, these trends were very unequal according to countries and continents ${ }^{5}$. The place in the world that lost the most linkages during the period is Great Britain, mostly in its intra-urban and intra-national linkages. However, Great Britain cities continued to increase their inter-continental linkages from 2010 to 2013. This principally confirms the position of London maintaining its centrality in worldwide financial networks. The other developed countries increased the number of their multinational firms' linkages at all scales, except Japan, where the local (intra-urban) level is decreasing. These countries also have approximately $50 \%$ of all their multinational firms' linkages within their national territory, which reveal a strong national base composed of a complex network of several national cities. Cities of these countries also exhibit strong complex internal networks among their own companies, whose reflect a high level of capitalism, where uncertainty is addressed locally by strong interactions and recombination between economic resources (Stark, 1996). This phenomenon is much less visible in the urban areas of the United States, where companies may have developed these interactions more intensively at an early stage at the national level.

During the 2010-2013 period, most of the emerging countries had rapid growth in the number of multinational firms' linkages, except Russia. China and South Africa increased more rapidly, particularly their national inter-urban linkages. Thus, their insertion in multinational firm networks, which was mainly inter-continental in 2010 and was induced by the external investments coming mostly from developed countries, was balanced in 2013 by more intra-national linkages possibly resulting from two simultaneous processes:

- An increase of national multinational enterprises supported by numerous national cities and

- A diffusion of foreign multinational enterprises in the national urban system.

Brazil also widely increased its number of multinational firms' linkages, but its share of intercontinental linkages remained high in 2013, thus revealing a delay in the process of reinforcement of its national urban system (19\% in 2010 to $25 \%$ in 2013$)$.

The differences in the expansion of multinational firms by countries and continents are not strictly due to urban processes. In fact, they depend partly on the bilateral and multilateral agreements made by nation-states and international economic institutions. However the national/continental cohesions are widely supported by the economies and social fabrics of cities. In fact, more than $90 \%$ of all multinational firms' headquarters and subsidiaries are located in large urban areas, where they participate in the local milieu and in external interurban exchanges. In this way, countries' development is mostly based on the capacity of their cities to contribute to the development of such networks.

\subsection{Cities' hierarchies according to multinational firms' networks}

Multinational firms are distributed among the cities of the world without introducing a strong hierarchy (Fig.2). In fact, the Rank-Size graphs of cities according to the number of ownership $\left(H_{i}\right)$ or subsidiary linkages $\left(S_{j}\right)$ result in a rather concave curve (in both 2010 and 2013 without any major change except a relative decrease in the first city for the number of ownerships [on the left graph: London] and a relative increase in the first city for the number of subsidiaries [on the right graph: again London]). In the language of

\footnotetext{
${ }^{5}$ We note that this total is not the sum of continents or countries because for the example of continents, inter-continental linkages count for each of them (counting twice, i.e., for both continents they concern). This explains why the proportion of inter-continental linkages is much higher for each continent than it is for the total.
} 
complex systems, one can say that this network of cities formed by the financial linkages between multinational firms is not strictly "scale free", which means that it is not organized according to a unique hierarchy of cities that would emerge from the globalization process. Conversely, the global pattern seems to consist of different subgroups whose connections form the whole system.

Figure 2: Hierarchies of cities worldwide according to the Network of multinational firms' ownership linkages (2010-2013)

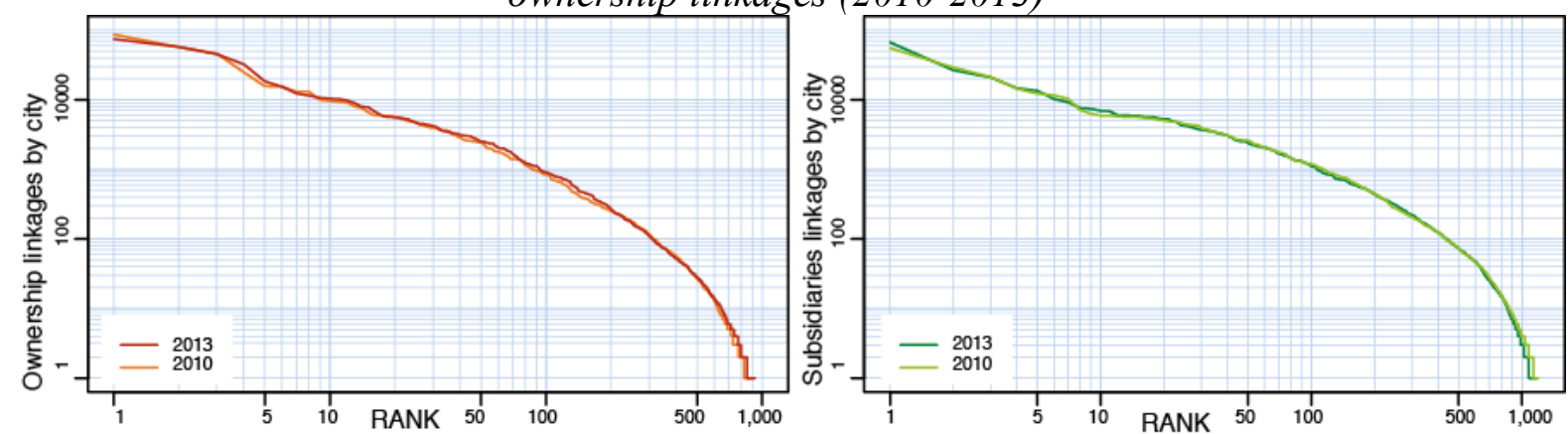

Some of these subgroups could have "small world" properties (Watts, Strogatz, 1998), which are consistent with the previous observation of a majority of linkages having national and continental scopes. Thus, different subsystems organize the worldwide network of multinational firms among cities. The question is now how to identify these sub-groups.

\section{Communities of cities forming the multipolar integration in globalization}

To identify the subsystems, we developed a clustering approach that detects communities or clusters as groups of cities densely connected to one another and sparsely connected to other clusters (Rozenblat et al., 2017). The Spin Glass clustering method (Reichardt \& Bornholdt, 2006) was applied on the 501 top cities (based on their number of non-oriented ownership linkages $\left.\left(H_{i}+S_{j}\right)\right)$ in 2010 and 2013 (Fig.3). 
Figure 3: Clustering of cities' networks according to multinational firms' ownership linkages

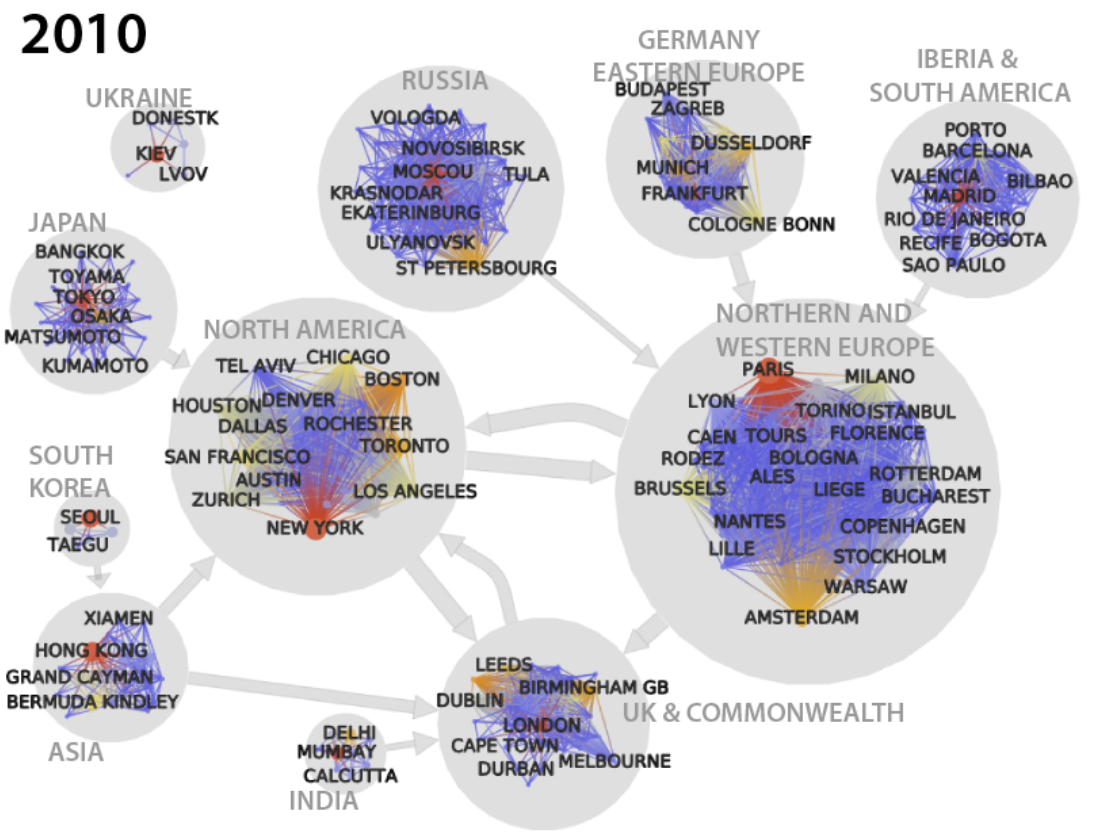

\section{3}

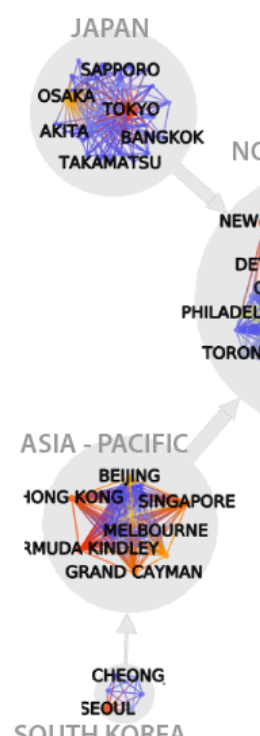

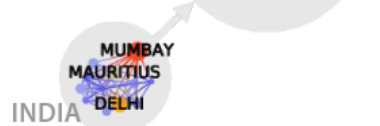

FRANCE
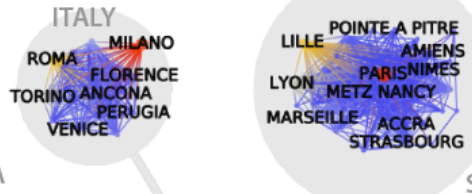

IBERIA \&

SOUTH AMERICA

SALVADOR

BARCELONA

ASTERN EUROPE

10. RUJEKA

DETROIT LOS ANGELES

ChaRLOTtE LINANGELES

TAIPEI

HOUSTON
BOSTON
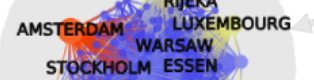

STOCKHOLM ESSEN
MUNICH NICOSIA FRANKFUR

STAVROPOL BURGAS
SARANSKROTTERDAM

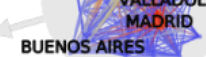

BUENOS AIRES \&

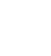

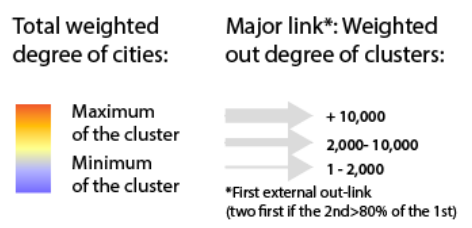

Number of cities in the clusters (max: 164):

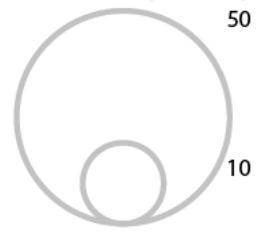

Bellwald, Rozenblat, Zaidi, 2015 Ori3, UNIL GeodiverCity, 2014 
This process results in two partitions that are similar at $75 \%{ }^{6}$ (i.e., $75 \%$ of the cities remain grouped in the same communities at both dates) (Fig.3). The overall pattern of these partitions exhibits 11 clusters encompassing $76 \%$ of the total linkages in 2010 and 10 clusters encompassing $71 \%$ of the total linkages in 2013.

In both cases, three classes constitute the core of the worldwide network: North American, UK and Commonwealth, and Northern Western Europe and African city clusters. They remain quite stable despite slight changes between 2010 and 2013.

Most of the "satellites" connected to this central structure remained the same between 2010 and 2013: The Iberian and South American group of cities remained dominated by Madrid, with $35 \%$ of the internal links, and Barcelona, followed by Bilbao, Lisbon, Sao Paulo, Seville, Valencia, Rio de Janeiro, Mexico City, Santiago de Chile and Buenos Aires.

The Japanese cluster encompasses nearly 30 cities at both dates, including all Japanese cities plus Bangkok, Jakarta and Maastricht. The class is dominated by Tokyo, which claims $45 \%$ of the total internal linkages, and by Osaka (25\%).

South Korea includes all six main South Korean cities. Similar to Tokyo, Seoul concentrates more than $40 \%$ of the internal links at the two dates, and Pusan concentrates $20 \%$.

The Indian community of 10 cities highlights the network cohesion of this sub-continental country and includes Mauritius and Colombo (Sri Lanka). Mumbai dominates this class, with $36 \%$ of the internal links, followed by Delhi with $23 \%$ and Chennai with $8 \%$.

The Asia-Pacific region is dominated by Chinese cities (Hong Kong, Beijing, Shanghai), and regroups the main Southeast Asian cities (Singapore, Kuala Lumpur). This class also includes tax havens, such as the Grand Cayman (8\%), Bermuda Kindley (10\%) and Tortola (Virgin Islands). Australian cities, which were closer to the UK and Commonwealth in 2010, joined this class in 2013 (Sydney, Melbourne, Perth and Brisbane).

Europe is the group that has the most slight changes, mostly by ungrouping or grouping by entire national urban systems: German, Eastern European, Russian and Ukrainian cities joined the main European cluster between 2010 and 2013. At the opposite end, French cities were isolated, led by Paris (39\% of the total internal links). This group includes the former French colonial cities in Africa (Tunis, Algiers, Douala, and Dakar) and Frenchspeaking capitals (Accra), all of which were already in the European cluster in 2010. The 35 Italian cities left the European group, including Lugano (an Italian-speaking city in Switzerland).

Therefore, a first major outcome of this clustering approach is the strong cohesion for most of the national urban systems in the world. Cities that belong to the same country, regardless of whether they are included in a wider continental community, remain mostly highly connected in the same clusters. Only in some rare cases such as Switzerland are the national cities divided between several groups: Zürich and Bern were encompassed in the

\footnotetext{
${ }^{6}$ To compare cluster partitioning, we used the Normalized Mutual Information (NMI) method, as proposed by Danon et al. (2005). Given two partitional structures of a network, the NMI calculates the proportion of couples remaining in the same groups and thus returns a value in a range between $100 \%$ (perfect similarity) and $0 \%$ (complete dissimilarity).
} 
group of American cities in 2010 or in the UK Commonwealth in 2013, whereas Geneva and Basel remain closer to Western European cities.

A second important outcome is the persistence of spatial proximity as a determinant factor in the constitution of these clusters. They often correspond to a long history of geographical relationships, during which the moves and communications were much more restrained by the physical distance. The role of physical distances survives today within the free trade zones that have been developed regionally throughout the world since the $2^{\text {nd }}$ World War and especially since the 1990s. In addition to the physical proximity, other historical factors such as the proximity induced by colonialism or common language persist through economic preferential linkages that may be reinforced by political and defense agreements. This explains the strong integration of United Kingdom cities with cities of the Commonwealth countries, cities of Spain and Portugal with South American cities, and French cities with those of France's former African colonies.

National cohesion and physical or cultural/historical distance remain the key components for understanding the multi-polar global economic integration in 2010 and 2013. The slight shifts between the dates are mostly due to the changes in enterprise network structures facing both long- and short-term global transformations. In that respect, one can easily assume that companies have different issues and strategies according to their activity sector.

\section{Multipolar integration of cities by activity sectors}

According to the literature underlying the specific role of advanced services in structuring the global urban system (Sassen, 1991) and the "multiple globalization" that varies according to the skill levels of industry or of services (Krätke, 2014), we computed the clustering again on partial networks defined for each large activity sector using the OECD (2009) nomenclature. Four large sectors are distinguished based on the nature of the activity and skill levels (Fig.4):

- High-technology manufacturing (HIGH-TECH) includes chemical and pharmaceutical industry and the computer, machinery, and motor industry.

- Low-technology manufacturing (LOW-TECH) encompasses food and beverages, textile, paper, coke and petrol, plastic, metal, and printing.

- Knowledge-intensive services (KIS) are composed by finance and insurance along with art, scientific activities, information and communication, transportation, health and social services.

- Less knowledge-intensive services (LKIS) include trade, real estate, administration, accommodations and food, and household services.

\subsection{Clustering cities by activity sectors}

The resulting clusters underline very similar grouping of cities: regardless of the activity sector, the same global networking pattern can be identified, including a core formed around the three central poles: North America, Europe and UK \& Commonwealth. The slight differences that appear reflect both the specific sectorial organization of firms and the specialization of cities or urban systems in some of these activities.

There are fewer classes for the two manufacturing sectors than there are for the two service sectors ( 8 and 7 for High-technology manufacturing in 2010 and 2013 and 10 and 9 for 
Low-technology manufacturing; 11 and 10 for Knowledge-intensive Services and 12 and 11 for Less Knowledge-intensive Services). This difference in the grouping level means that more globalization has been achieved in manufacturing than in services.

- For High-technology manufacturing, Japanese cities are very well positioned in globalization, thanks to their powerful and numerous keiretsu in the electronic and motor industry. After being close to North American cities in 2010, they reoriented their dominant connections toward Europe and the UK and Commonwealth due to a rise of investments in the more recent period. Investments also increased in this sector between Europe and South Korea, which became closer in 2013, and between the UK and India.

- For Low-technology manufacturing, a Middle Eastern community of cities formed by Beirut, Riyadh and Kuwait in 2010 rejoined North America in 2013. Bahrain, Dubai and Haman are encompassed in the UK \& Commonwealth community. This community also includes China and Australia in 2010, leaving the group in 2013. Europe is in both High-technology and Low-technology manufacturing, which was more unified in 2013 than it was in 2010, revealing the growth of continental linkages compared to national ones.

- For services (Fig.4, continuing), Europe is divided into more numerous groups: In the Knowledge-intensive services clustering, Scandinavian cities are isolated at both dates, whereas French and Italian ones separate in 2013. This European segmentation has a stronger emphasis for Less knowledge-intensive services. Europe was divided into 6 groups in 2010 and 7 groups in 2013. In addition, the community of UK and Commonwealth is more powerful for services than for manufacturing. It includes in 2010 most Eastern Asian and Pacific cities (excepted Japanese and Korean cities) and Tax Haven cities. For Knowledge-intensive services, the UK and Commonwealth community polarized much more than did the other groups in 2013. Therefore, the repositioning of London with fewer national linkages and more worldwide ones, as noted in the section 2.3 of this chapter, is specified here by the restructuring of the Knowledge-intensive services around the UK and Commonwealth cities' community.

Thus, when comparing manufacturing and service cities' clusters, the outcome is more global (and less numerous) clusters for industrial activities than for services, with the latter remaining more developed inside national boundaries. This difference emphasizes that the globalization of services, despite the high integration of the core cities such as London, New York and Tokyo (Sassen, 1991) by the international network of stock exchange, remains much less internationalized and more embedded in the national economies compared to the globalization of manufacturing. In fact, advanced service providers such as advisors and lawyers must be aware of national rules and laws in close connection with national institutions that continue to develop their own systems and require specific expertise. In contrast, industrial globalization has, for a long time (almost one century), developed an international division of labor, which has created a more globalized and more complex and dense international city system. 
Figure 4: Clustering of cities' networks by activity skill level

\section{A- HIGH TECH}

2010

8 classes encompassing $67 \%$ of total links

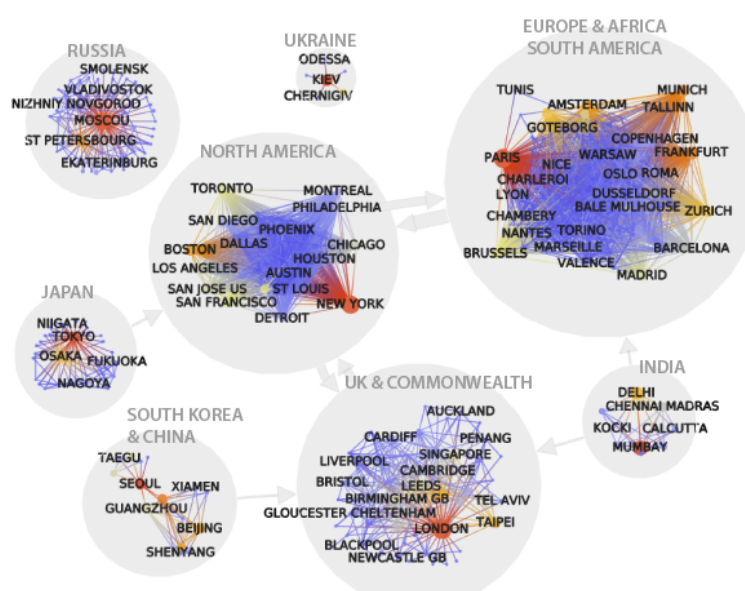

\section{B- LOW TECH}

2010

10 classes encompassing $70 \%$ of total links

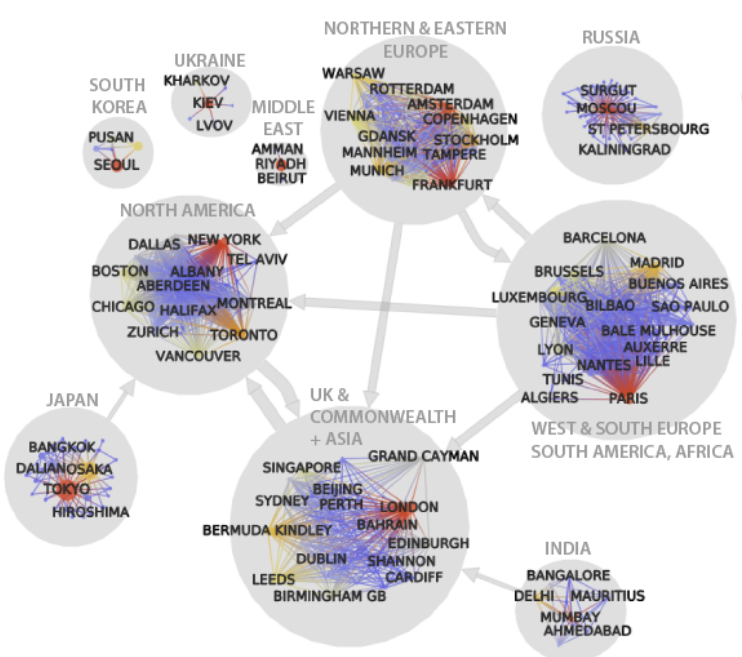

2013

7 classes encompassing $70 \%$ of total links

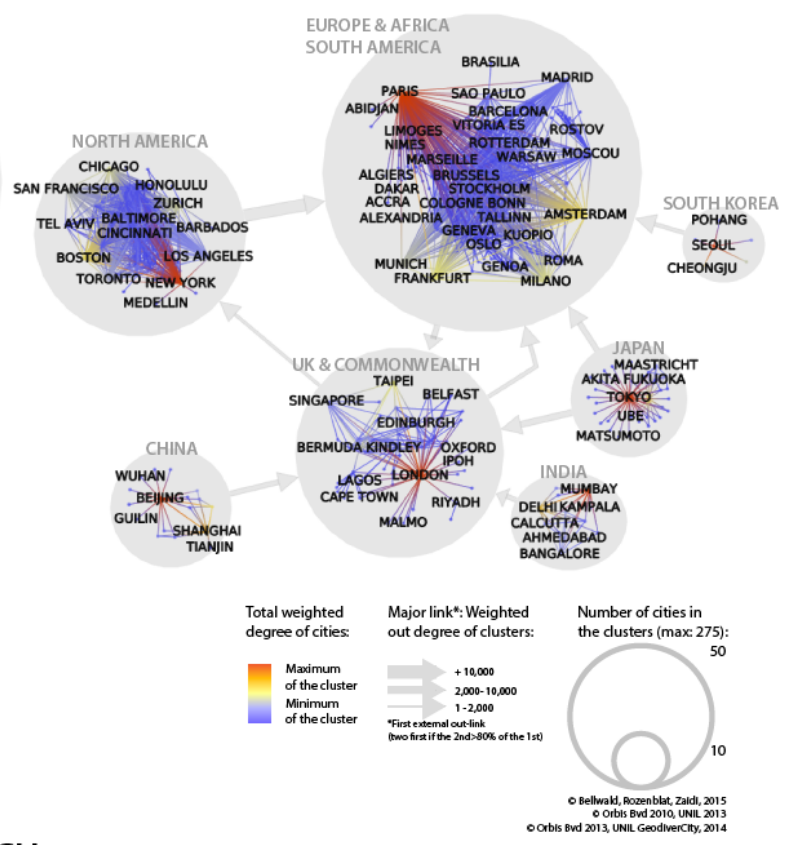

2013

9 classes encompassing $83 \%$ of total links

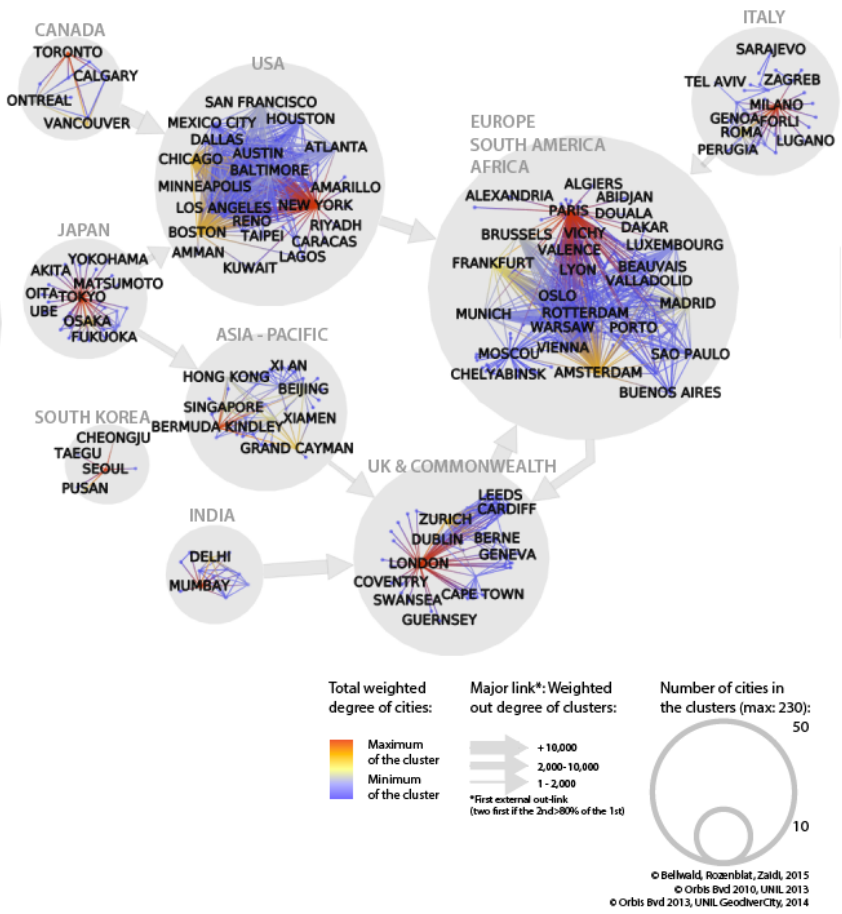


Figure 4 (continuing): Clustering of cities' networks by activity skill level

\section{C- KNOWLEDGE INTENSIVE SERVICES (KIS)}

2010

11 classes encompassing $76 \%$ of total links

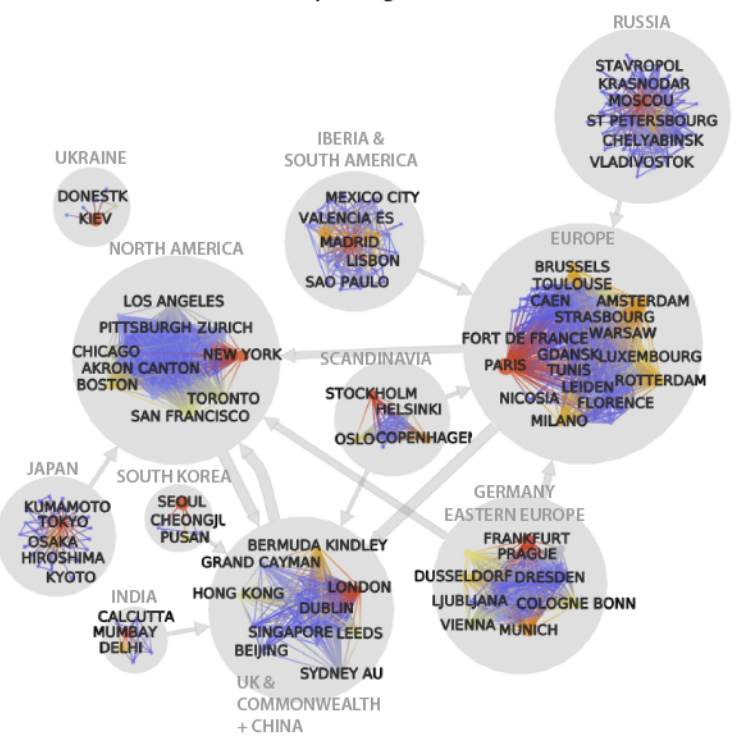

D- LESS KNOWLEDGE INTENSIVE SERVICES (LKIS)

2010

12 classes encompassing $77 \%$ of total links

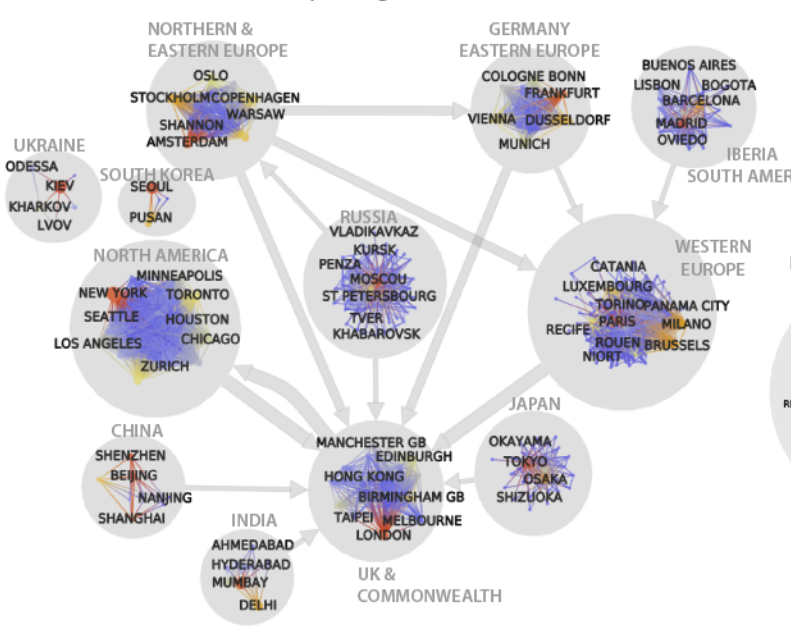

2013
2013

10 classes encompassing $85 \%$ of total links

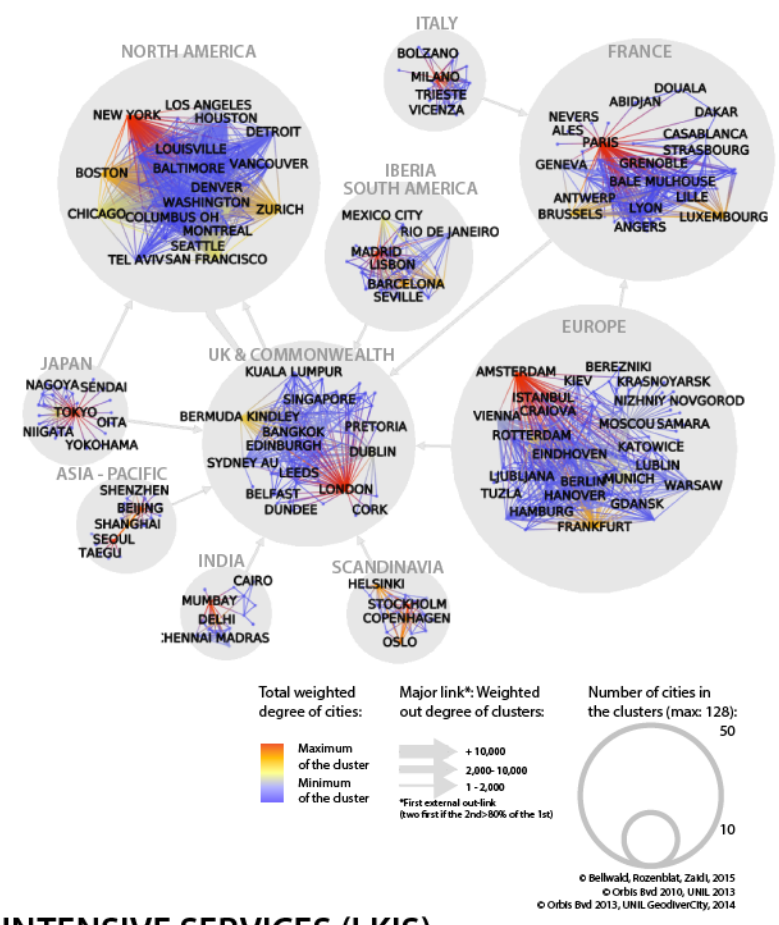

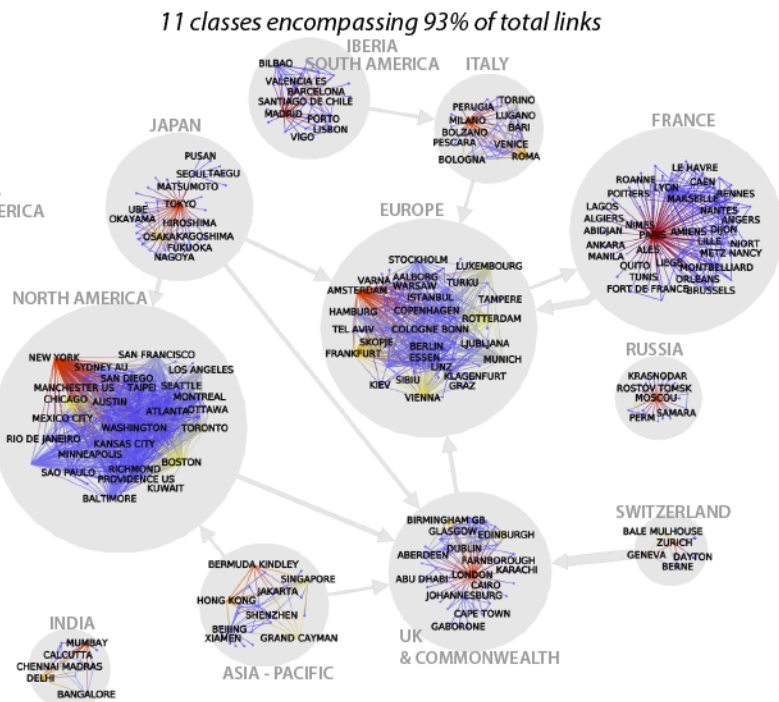

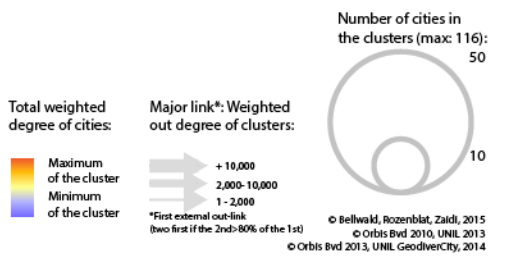




\subsection{Evolution of cities' networks by activity sectors}

To understand the general feature each category of activities creates in the Cities' system as a whole, we compare the rank-size hierarchy of cities for each category in 2010 and 2013 (Fig.5).

Figure 5: Hierarchies of cities according to their networks by activity skill level
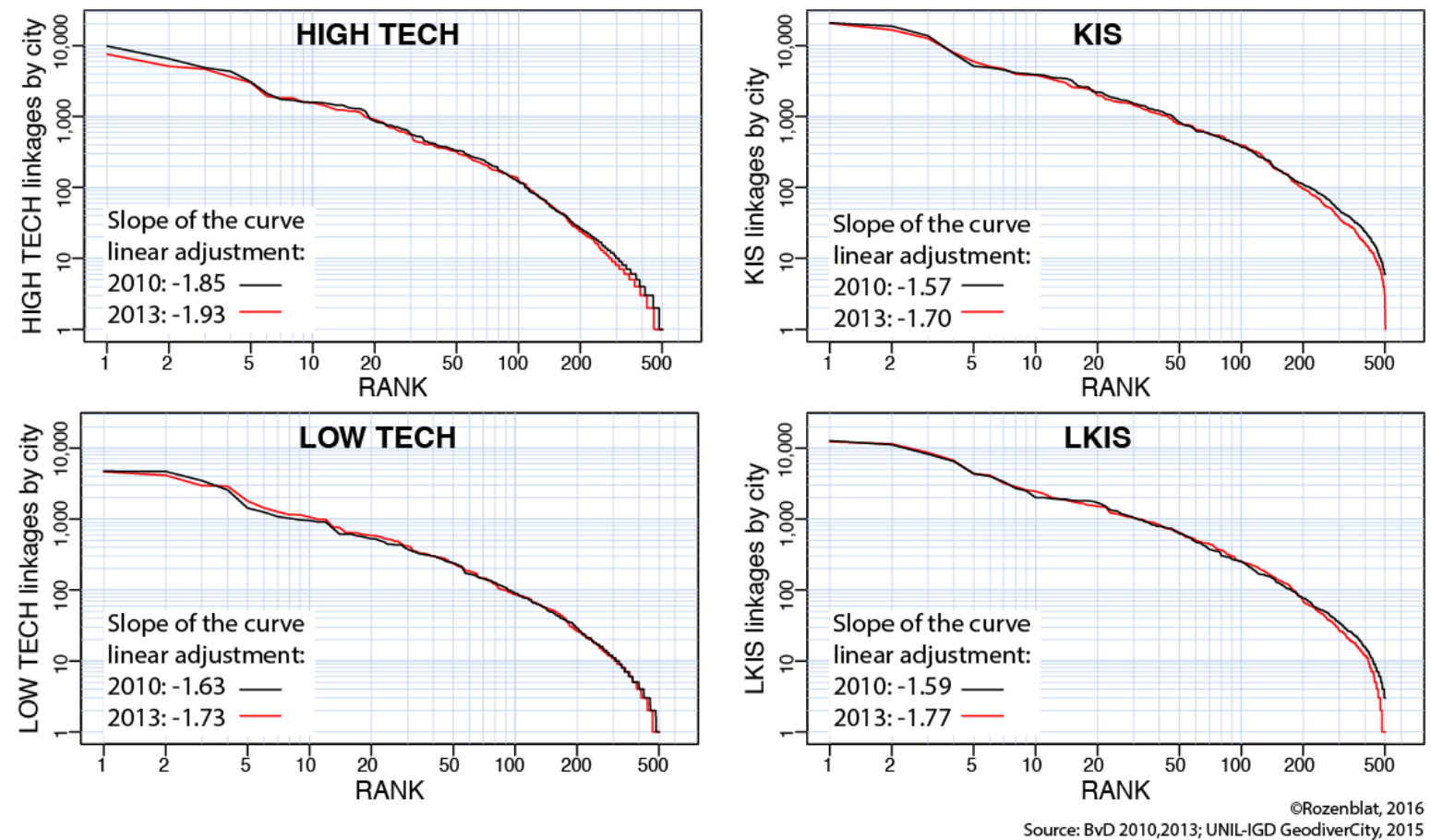

In general, industrial networks hierarchize more cities than do service networks. This delay comes from the advanced stage of industry in the globalization process, which creates an urban system that is closer to a unique hierarchy of cities (despite a remaining dominant multi-polar shape). However, this delay tends to diminish between 2010 and 2013 because of the faster hierarchization of cities by services induced by their globalization integration (which is also visible in the decreasing number of clusters).

For High-technology manufacturing and Knowledge-intensive services, the 2013 curves are very similar to the 2010 ones, and the changes are perceptible only in the top of the hierarchy for High-technology manufacturing: New York and London, which remained the two first cities, lost $20 \%$ of their linkages, whereas Tokyo surpassed Paris for third place. For Knowledge-intensive services, London maintained its first rank, keeping the same number of linkages (that redeployed more in long-distance scopes), whereas New York and Paris remained second and third, with a $10 \%$ decrease in the number of linkages. In both cases, the following cities did not take advantage of these top re-compositions. In contrast, after the three top ranks, the 2013 curve is below the 2010 one.

For Low-technology manufacturing and Less knowledge-intensive services, the top cities' hierarchy did not change significantly. However, the cities shifted slightly from the $4^{\text {th }}$ to the $30^{\text {th }}$ rank for Low-technology manufacturing and from the $30^{\text {th }}$ to the $200^{\text {th }}$ rank for LKIS. For Low-technology manufacturing, this shift reveals the affirmation in the command functions of large metropolises either in developed countries, such as Boston, Chicago, San Francisco, Osaka, Zürich, Toronto, Vancouver, Amsterdam, Milano, and Frankfurt, or in emerging countries, such as Mumbai, Singapore and Beijing. For Less 
knowledge-intensive services there is a general growth of all national capitals and secondtier cities in the largest urban systems, thus benefiting a slow diffusion of the globalization of their services.

The evolutions of the cities' communities for the four categories of activities can also be evaluated using the NMI index, which measures the similarity between the communities obtained in 2010 and in 2013 (see note 6). The comparison is summarized in table 2:

Table 2: Evolution of clustering of cities' networks by activity skill level

\begin{tabular}{|l|c|}
\hline & NMI 2010-2013 \\
\hline HIGH TECH & 0.78 \\
\hline LOW TECH & 0.61 \\
\hline KIS & 0.80 \\
\hline LKIS & 0.73 \\
\hline TOTAL NETWORK & 0.75 \\
\hline
\end{tabular}

Source: BvD 2010,2013; UNIL-IGD GeodiverCity, 2015

The NMI indexes evaluate for each clustering its level of change. A high similarity reveals very slow evolution, whereas a lower similarity underlines more transformations. According to these differences, the manufacturing networks were more modified than the service networks, and in both categories, the spatial organization of lower skill activities was more transformed than those of higher skills. We can interpret this result from the perspective of the evolutionary theory of urban systems: lower-skill activities belong to a more mature economic cycle and are diffused in a larger number of cities than are higherskill activities.

One can wonder if the evolution of the four clustering led them to converge or, contrarily, to diverge. The answer to this question can be addressed again by the NMI indexes, put in matrices, which compare for each date the cities' clusters according to the four activities (Tab. 3):

Table 3: Similarity between clustering of cities' networks by activity skill level

\begin{tabular}{|l|c|c|c|c|}
\hline NMI-2010 & HIGH TECH & LOW TECH & KIS & LKIS \\
\hline HIGH TECH & 1 & & & \\
\hline LOW TECH & 0.75 & 1 & & \\
\hline KIS & 0.72 & 0.76 & 1 & \\
\hline LKIS & 0.68 & 0.74 & 0.80 & 1 \\
\hline
\end{tabular}

\begin{tabular}{|l|c|c|c|c|}
\hline NMI-2013 & HIGH TECH & LOW TECH & KIS & LKIS \\
\hline HIGH TECH & 1 & & & \\
\hline LOW TECH & 0.72 & 1 & & \\
\hline KIS & 0.65 & 0.67 & 1 & \\
\hline LKIS & 0.56 & 0.65 & 0.78 & 1 \\
\hline \multicolumn{5}{|c|}{ (ORozenblat, 2016 }
\end{tabular}

Source: BvD 2010,2013; UNIL-IGD GeodiverCity, 2015

The NMI similarity measures show that the city clusters in 2013 are less similar than those obtained in 2010. Despite the general similarity between the specific activity clustering results that we noted in 4.1, there was a slight divergence of the cities' network shapes between the dates. Whereas the most central cities (London, New York, Paris, Tokyo) were diversified, continuing to dominate all four networks, each city and sub-urban system tended to develop toward a specific domain, making the whole urban network more complex (observed by the regular decrease of the number of clusters between 2010 and 2013).

This trend of specialization and growth of complexity would certainly be a part of the long-term process of activity cycles, in which mature activities diffuse hierarchically through urban systems (see Chapter 1 in this volume). In the meantime, the shifts between London, New York, Paris and Tokyo can be seen as a result of the recent crisis that could constitute bifurcations that can transform the whole global urban system from a long-term 
perspective.

\section{Discussion of the factors influencing cities' global multipolar integrations}

The previous empirical study permitted us to evaluate cities' integration in globalization within the processes that act at the global level of the whole urban system. To understand such positions, we often need to mobilize the local, national or continental history and path dependence. Putting into perspective the previous results leads to a wider discussion of the main local and national specific factors that unevenly influence cities' global integration.

\subsection{Clusters' internal hierarchies and hubs}

Most of the dominant cities of the central clusters correspond to cities that are classically mentioned as "world cities": London, New York, Tokyo, Paris, and Amsterdam. The regularity of these cities' centrality in the service and industrial sectors confirms the correlation highlighted by Wall \& Van der Knaap (2011). Moreover, the results demonstrate that the capital cities of peripheral regions constitute intermediary for cities of their subsystems reminding the "pivotal intermediary" property that Meyer (1986) defined for Mexico City. The level of their cluster domination and their clusters' hierarchical characteristics underline the complexity of the global urban system, better than the core/hinterland results of the previous studies on the regionalization of the world city networks (Taylor et al., 2002, 2013; Derudder et al., 2003; Alderson \& Beckfield, 2004).

Adopting the multi-polar perspective, we managed to evaluate the extent to which the "classical world cities" do not have the same levels of dominance (polarization) in their own clusters, which reveals different forms of globalization:

- On the one hand, the cities that dominate their clusters compose more than half of the total out-linkages of their respective clusters. These dominant cities are London, Tokyo, Paris, Milan and Seoul. They concentrate a high intermediary capacity for decisions, playing a central role in the globalization of other cities in their own sub-systems. The best example of this type of worldwide role is London, encompassing global control of numerous cities around the world. Other cities, such as Tokyo, Paris, Milan and Seoul, primarily control their national urban systems.

- On the other hand, New York for North American cities, Amsterdam for Northern and Eastern European cities, and Beijing for Asian-Pacific cities belong to more distributed systems, in which many cities exchange firms' linkages all together and directly with cities from other clusters.

\subsection{Cities' clusters at the regional and national scales}

In addition, the multipolar system of cities does not function on the same scale around the world. The fact that some continental, inter-continental or national scales appear at the same scale of cluster cohesion expresses a wide range of levels of global openness/cohesion of cities by countries and continents. For Less Knowledge-intensive services, Japanese, Korean, Indian, Chinese, French, Italian and even Swiss cities constitute single groups that are characterized by a high cohesion level of their national cities' networks. These national networks produce the same level of interdependencies that 
exist in much wider regional or global communities, such as North America, the UK and Commonwealth or Iberia and South America.

The boundaries of the clusters of cities' networks do not always strictly correspond to national borders. For example, the Japanese cluster also includes South Eastern Asian cities such as Bangkok, Manila or Jakarta, especially for High-technology activities (Fig.6).

Figure 6: Japanese cluster of cities for HIGH TECH networks

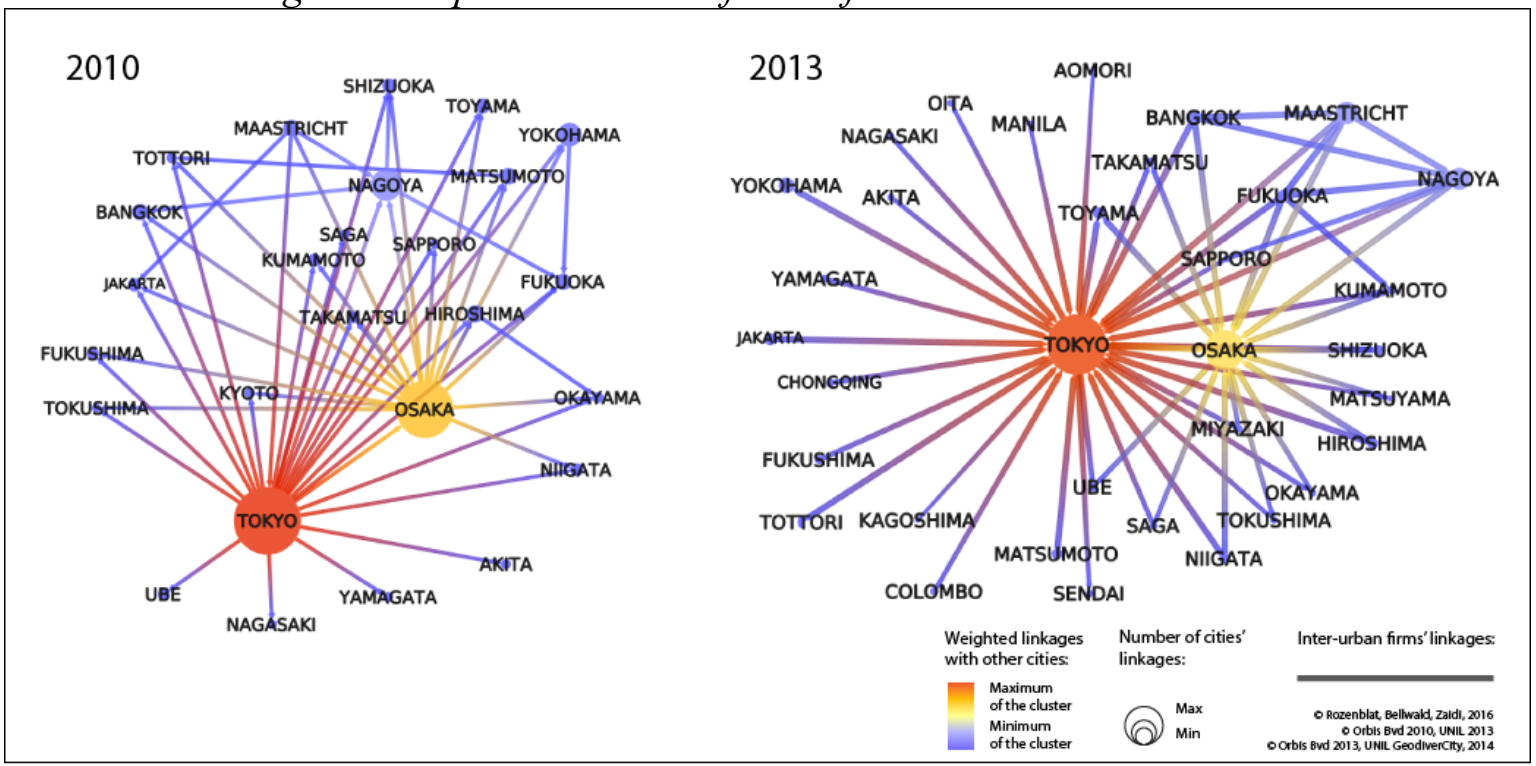

Here, Tokyo and Osaka develop their influence beyond Japanese boundaries. South Korea and Australia, which are economically close to Japan (for both, Japan is the second largest export country after China [UNCTAD, 2014]), remain a distinct sub-system in the case of South Korea, whereas Australian cities belong to UK and Commonwealth or Asian cities communities.

\subsection{Cities with a long-range integration: Economic specialization and specific factors}

Cities that belong to different clusters according to their activities have a particular position in the globalization process. They constitute specialized or regional pivots in the expansion of multinational firms' strategies, hosting regional or specialized centers of industry or services. These cities are principally located in Asia, Australia and South America, plus Zurich and Tel Aviv. Most of them move between UK \& Commonwealth, North American or European clusters.

The representation of the UK \& Commonwealth KIS cluster (Fig.7) offers a partial view of these cities, which are in different clusters, depending on the activity and the period of time. In that particular case, London's influence, beyond other UK cities, exists in 2010 Tax Haven places (Grand Cayman, Bermuda Kindley, Barbados), Asian major metropolises (Hong-Kong, Singapore, Taipei, Kuala Lumpur, Jakarta, Karachi, Beijing, Shanghai), Middle Eastern cities (Riyadh, Amman, Beirut, Kuwait, Cairo, Algiers), and African cities (Nairobi, Accra and South African cities). As of 2013, Tax Haven places and Australian cities remain in this UK \& Commonwealth KIS cluster, but Chinese cities (except Hong-Kong) have left, forming a new cluster with South Korean cities. Middle Eastern cities mostly joined Indian cities by 2013. In contrast, the UK \& Commonwealth cluster has expanded in Africa to Lagos, Kampala, Gaborone, Blantyre and Dar Es Salaam. 
Figure 7: UK \& Commonwealth cluster of cities for KIS networks (2010-2013)

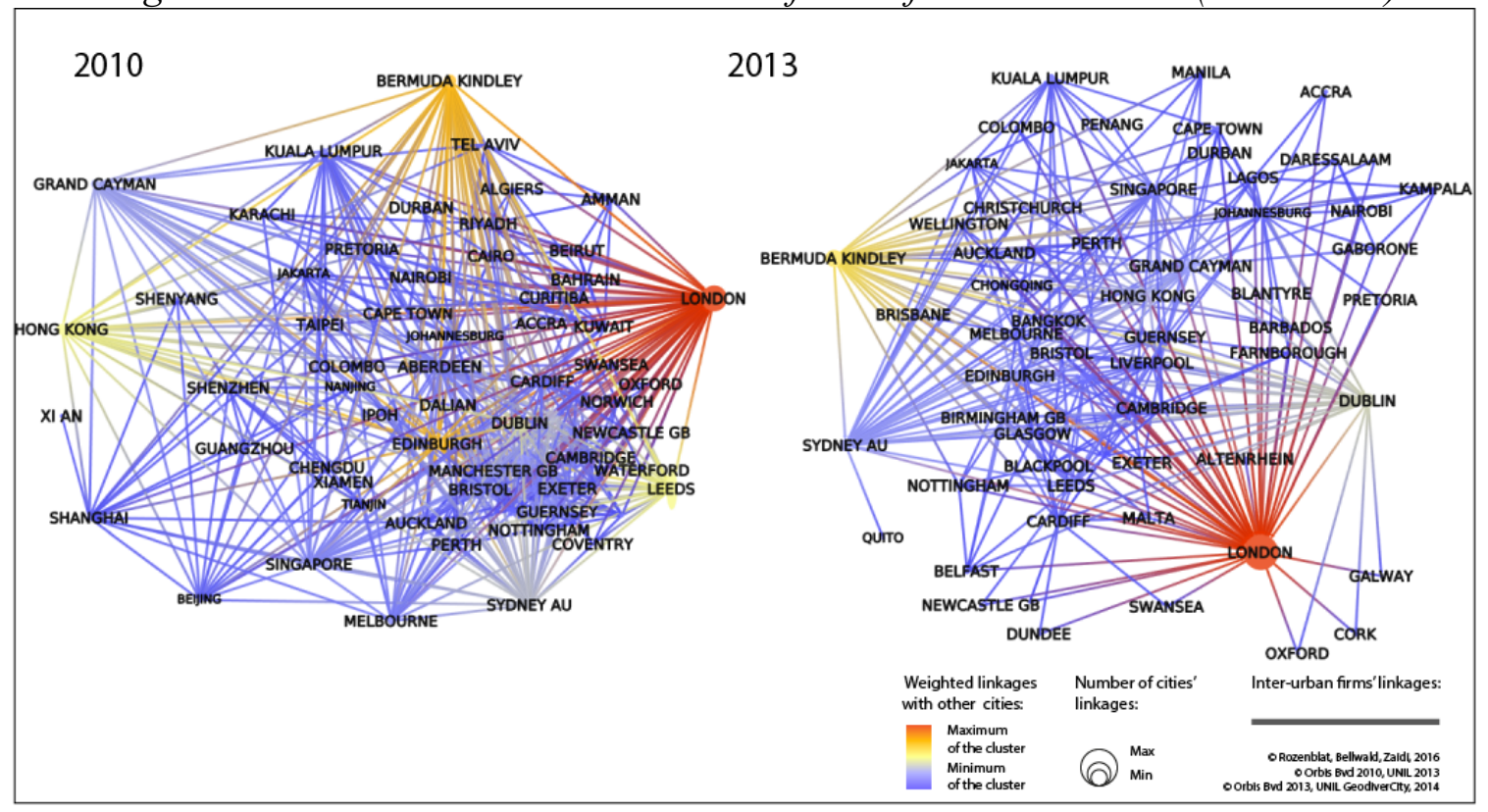

Thus, the influence of Knowledge-intensive services of the UK was quite transformed in only a few years, mostly because of the expansion of London long-range linkages on the one hand and the bottom-up development of Asian cities on the other hand.

\subsection{The special case of City-states}

The bottom-up emergence of cities in these global processes impacts entire urban systems but also single cities. Some of these cities, which seem to no longer be embedded in national urban systems, deserve special attention. These forms of what is occasionally called "city-states", emerge owing to the transnational trade, migration or capital, operated by people, firms or institutions that transgress national boundaries and organize their activities or trajectories beyond frontiers, and one can observe them in the multinational firms' networks.

City-states have very different histories, but they often (but not always) share a common role as a transportation hub. In the Asian area, Hong Kong and Singapore had important roles as maritime and air hubs during the second half of the $20^{\text {th }}$ century (Murayama, 2000). In the 2000s, Luxemburg also became the first European hub for air-freight (supported by the Luxemburgish plant of the main European center of Amazon). From this perspective, Abu Dhabi, Dubai or Doha benefited from the petro-dollars investments in new air companies (Emirates and Qatar Airways), which made them major hubs between Europe, Africa and Asia. Accessibility is a sine qua non condition of being integrated in globalization, but it is not sufficient. National policies leveraged their role also by branding, with famous architectural, artistic, political or sporting events aimed at appearing as a world flagship.

Last but not least is the tax haven characteristic. Thanks to their tax advantages, some citystates are particularly active in linking groups of cities for highly skilled activities. Hong Kong, Singapore, Kuala Lumpur and Luxemburg play a large role in the global organization of advance business services in complementary world cities (Wojcik, 2013). In the clustering approach that we developed on multinational firm networks, most of these 
Tax Haven cities appear in the Knowledge-intensive service cluster of the UK \& Commonwealth, participating in the higher business game of the world. However, not all of the Tax Haven places benefit from real power and diversified urban development, as is observed in the "dubaization" phenomena. This "dubaization" concept describes the locally initiated development aiming to leverage a new world financial center and transforming the oil economy into a "local post-oil company" (Elsheshtawy, 2010). Bermuda Kindley and the Grand Cayman and Virgin Islands, despite their confirmed role in the global finance, cannot be considered as metropolises, but are rather characterized as offshore places depending on London and other global cities (Wojcik, 2013).

Although some of these cities have been concentrated for 25 years, with specific efforts to satisfy the necessary conditions for strong global integration into the "global metropolitan culture" that is characterized by a similar urban environment and way of life (Harvey, 2012; Rossi, 2017), one can wonder if they are so different from other cities that are more embedded in their national urban systems.

First, many cities that are qualified as city-states, actually belong to national urban systems that are stronger than one usually assumes (Tab.4). Only three cities have the status of a state: Singapore, Hong Kong, and Macau (the last two ones are not real states but are territories with specific status). In addition, very few cities concentrate more than half of the population of their states and are neither major tax haven nor metropolises that count in global flows. The only most-populated city that appears both in this primacy table and in the tax haven lists is Panama City (Wojcik, 2012). Panama City enjoys all of the previously mentioned factors, such as accessibility (the obliged corridor between Atlantic and Pacific) and tax advantages. In global clustering, it occasionally belongs to North America (for Knowledge-intensive services and High-technology manufacturing), Iberia and South America (for Less Knowledge-intensive services) and London and the Commonwealth cluster (for Low-technology manufacturing). In this way, it is similar to Tel Aviv and Zürich, which belong to different clusters depending to the activity considered. These cities can be qualified as very global in this way.

Second, the other cities that have a high value in Table 4 are primary cities in their urban system serving as a gatekeeper pole of integration in globalization. They concentrate most of the population, economy and institutions of their country, and they drive their national urban system in their cluster. The development of their national urban system depends widely on the type of governance decentralization.

For example, in Japan, urban development has been planned since the 1960s at the regional and prefectural levels to regulate the territorial equilibrium, avoiding a rise of the hyperconcentration in Tokyo that was already very high (see Abe et al., Chapter 7 in this volume). Tokyo still polarizes most of the economic networks, as confirmed by the permanent high cohesion of the Japanese cluster of cities. For Argentina, the primacy of Buenos Aires remains very high, despite some policies attempting to strengthen the secondary poles and the colonization of rural settlements (Cuervo Gonzalez \& Moura, Chapter 8 in this volume). Buenos Aires also plays the dramatic role of a gateway for the global linkages of all national cities. In these two examples, as observed in many countries, primacy cities are the key factor of the national cohesion that is observed throughout the clustering study. 
Table 4: Similarity between clustering of cities' networks by activity skill level (2010-2013)

\begin{tabular}{|c|c|c|c|c|c|c|c|c|c|c|c|c|c|}
\hline 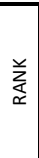 & COUNTRY & CITY & $\begin{array}{l}\text { City } \\
\text { population } \\
1950 \\
(\text { in }, 000)\end{array}$ & $\begin{array}{l}\text { City } \\
\text { population } \\
2015 \\
(\text { in }, 000)\end{array}$ & $\begin{array}{l}\text { Percentage } \\
\text { of the city's } \\
\text { population } \\
\text { in its own } \\
\text { country in } \\
1950\end{array}$ & $\begin{array}{l}\text { Percentage } \\
\text { of the city's } \\
\text { population } \\
\text { in its own } \\
\text { country in } \\
2015\end{array}$ & 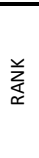 & COUNTRY & CITY & $\begin{array}{l}\text { City } \\
\text { population } \\
1950 \\
(\text { in }, 000)\end{array}$ & $\begin{array}{l}\text { City } \\
\text { population } \\
2015 \\
(\text { in }, 000)\end{array}$ & $\begin{array}{l}\text { Percentage } \\
\text { of the city's } \\
\text { population } \\
\text { in its own } \\
\text { country in } \\
1950\end{array}$ & $\begin{array}{l}\text { Percentage } \\
\text { of the city's } \\
\text { population } \\
\text { in its own } \\
\text { country in } \\
2015\end{array}$ \\
\hline 1 & $\begin{array}{l}\text { China. Hong } \\
\text { Kong SAR }\end{array}$ & Hong Kong & 1682 & 7314 & 85 & 100 & 22 & Japan & Tokyo & 11275 & 38001 & 14 & 30 \\
\hline 2 & Singapore & Singapore & 1016 & 5619 & 99 & 100 & 23 & Bahrain & Manama & 40 & 411 & 34 & 30 \\
\hline 3 & $\begin{array}{l}\text { China. Macao } \\
\text { SAR }\end{array}$ & Macao & 190 & 584 & 99 & 100 & 24 & Estonia & Tallinn & 223 & 391 & 20 & 30 \\
\hline 4 & Kuwait & Kuwait City & 63 & 2779 & 41 & 71 & 25 & New Zealand & Auckland & 319 & 1344 & 17 & 30 \\
\hline 5 & Puerto Rico & San Juan & 451 & 2463 & 20 & 67 & 26 & Georgia & Tbilisi & 612 & 1147 & 17 & 29 \\
\hline 6 & Djibouti & Djibouti & 20 & 529 & 32 & 60 & 27 & Liberia & Monrovia & 35 & 1264 & 4 & 28 \\
\hline 7 & Uruguay & Montevideo & 1212 & 1707 & 54 & 50 & 28 & $\begin{array}{l}\text { Dominican } \\
\text { Republic }\end{array}$ & $\begin{array}{l}\text { Santo } \\
\text { Domingo }\end{array}$ & 180 & 2945 & 8 & 28 \\
\hline 8 & Mongolia & Ulaanbaatar & 70 & 1377 & 9 & 47 & 29 & Portugal & Lisbon & 1304 & 2884 & 15 & 28 \\
\hline 9 & Israel & Tel Aviv-Jaffa & 418 & 3608 & 33 & 45 & 30 & Greece & Athens & 1347 & 3052 & 18 & 28 \\
\hline 10 & Panama & Panama City & 171 & 1673 & 20 & 43 & 31 & Guinea-Bissau & Bissau & 18 & 492 & 3 & 27 \\
\hline 11 & Gabon & Libreville & 15 & 707 & 3 & 41 & 32 & $\begin{array}{l}\text { United Arab } \\
\text { Emirates }\end{array}$ & Dubai & 20 & 2415 & 29 & 26 \\
\hline 12 & Congo & Brazzaville & 83 & 1888 & 10 & 41 & 33 & Gambia & Banjul & 26 & 504 & 10 & 25 \\
\hline 13 & Lebanon & Beirut & 322 & 2226 & 24 & 38 & 34 & Ireland & Dublin & 626 & 1169 & 21 & 25 \\
\hline 14 & Chile & Santiago & 1322 & 6507 & 22 & 36 & 35 & Azerbaijan & Baku & 897 & 2374 & 31 & 24 \\
\hline 15 & Paraguay & Asuncion & 258 & 2356 & 18 & 35 & 36 & Costa Rica & San Jose & 148 & 1170 & 15 & 24 \\
\hline 16 & Argentina & Buenos Aires & 5098 & 15180 & 30 & 35 & 37 & $\begin{array}{l}\text { TFYR } \\
\text { Macedonia }\end{array}$ & Skopje & 120 & 503 & 10 & 24 \\
\hline 17 & Armenia & Yerevan & 341 & 1044 & 25 & 35 & 38 & Mauritania & Nouakchott & 3 & 968 & 0 & 24 \\
\hline 18 & Qatar & Doha & 18 & 718 & 72 & 32 & 39 & Senegal & Dakar & 214 & 3520 & 9 & 23 \\
\hline 19 & Peru & Lima & 1066 & 9897 & 14 & 32 & 40 & Haiti & Port-au-Prince & 133 & 2440 & 4 & 23 \\
\hline 20 & Latvia & Riga & 490 & 621 & 25 & 32 & 41 & Malaysia & Kuala Lumpur & 262 & 6837 & 4 & 23 \\
\hline 21 & Qatar & Ar-Rayyan & 2 & 677 & 8 & 30 & 42 & Denmark & Copenhagen & 1216 & 1268 & 28 & 22 \\
\hline
\end{tabular}

Third, complementarily to national policies of decentralization that have been developed in many countries for five decades, the independence of cities regarding their national governments has meant a general movement observed in cities of the world since the 1990s. This trend developed first in large city-regions with different temporal stages and consequences because of uneven contexts that nevertheless had a common cause: "The rise of entrepreneurial city induced by economic globalization and the retreat of national government in policy making, has been accompanied by cities' efforts to "delink" or decouple themselves from their respective national economies" (Short \& Kim, 1999, p.128). Lever (1997), focusing on European cities, observed that a very small number a cities were able to break out from their national general conditions, identifying Barcelona, Frankfurt, or Milan as delinking their national economies, with their rates exceeding national performance or through specialization in specific sectors. In fact, very few cities in the world have managed to realize this decoupling: their national urban system remains a high determinant for cities' integration in globalization. Both primary cities and cities' common membership to countries, their institutions, their economic and social system and their culture maintain strong mutual inter-dependencies between cities within national systems. 


\section{Conclusion: Partitioning cities of the world according to multipolar urban networks}

This chapter aimed to identify the sub-systems of cities that form the whole pattern of cities' integration at the global scale. Indeed, the assumption was confirmed that the most intensively interconnected cities form sub-systems that compose the global network, which is not structured around a single center but rather appears as a multi-polar world (Rozenblat et al., 2017). Identifying these sub-systems enables us to understand the common trajectories and contrasted evolution of cities since the middle of the $20^{\text {th }}$ century, which will be detailed in the next regional/national chapters. In analyzing the globalization process through a urban system perspective, we can determine the extent to which some national inherited structures remain relevant to understanding urban dynamics and the extent to which new geographical levels have appeared between the local and the global.

Although the integration of urban systems inside multinational firm ownership networks represents only a part of the globalization process in one of its financial aspects, it reveals the pervasive role of national cohesion between cities and the emergence of new continental or regional solidarities as well as historical footprints of ancient empires that remain alive today

The multi-polar vision of world cities that we developed corresponds to a wider change in the comprehension of the feedback processes maintaining or transforming cities' insertion in globalization. The classical core/peripheral system is replaced by a two-level system that considers the cores and peripheries both between and within clusters. Free trade zones and continental proximities are important in this stepwise process, participating in the feedback maintenance and reinforcement of the global strength of the central cities of some of the clusters.

Overall, we demonstrated in this chapter that national urban systems remain very cohesive, because cities of the same country exchange more together than with other foreign cities. This confirms the relevance of the concept well illustrated in the scholars on urban systems for over 30 years in the IGU urban commission and coined in the context of globalization under the expression of the "nested city" by Hill and Fujita (2003). In addition, cultural distance and economic specialization play a secondary role that is not as strong as national cohesion. This is demonstrated, for example, by the isolation of the Chinese urban system from London's advance business services influence (in KIS) during the period 2010-2013, thanks to the rapid development of China's own multinational firms of advanced services preferentially expanding their networks within the national territory.

The 2010-2013 evolution shows only very few transformations of the whole multi-polar global system. Thus, despite the complexity of today's delineation of urban systems, the results produced here by using the city network approach offer relevant partitioning that can partly orient the way in which we organize this book. Of course, it represents only part of the story of the development of urban systems; in complement, we must account for their demographic dynamics while highlighting other aspects of their systemic trajectories. 


\section{References:}

Acemoglu, D., Johnson, S., \& Robinson, J. A. (2001). Reversal of fortune: Geography and institutions in the making of the modern world income distribution (No. w8460). National bureau of economic research.

Alderson, A. S., \& Beckfield, J. (2004). Power and Position in the World City System. American Journal of Sociology, 109(4), 811-851.

Cohen R. (1981). The new international division of labor: Multinational corporations and urban hierarchy. In Dear M. and Scott A., eds, Urbanization and Urban planning in capitalist society, London: Methuen, pp.287-315

Danon L., Diaz-Guilera A., Duch J., \& Arenas A. (2005). Comparing community structure identification Journal of Statistical Mechanics: Theory and Experiment, IOP Publishing.

Derudder, B., \& Taylor, P. (2005). The cliquishness of world cities. Global Networks, 5(1), 71-91.

Derudder B., Taylor P.J, Witlox F., \& Catalano G. (2003). Hierarchical tendencies and regional patterns in the world city network: a global urban analysis of 234 cities. Regional Studies, 37(9), 875-886.

Easterly, W., \& Levine, R. (2001). What have we learned from a decade of empirical research on growth? It's Not Factor Accumulation: Stylized Facts and Growth Models. The world bank economic review, 15(2), 177-219.

Elsheshtawy, Y. (2010). Little space, big space: everyday urbanism in Dubai. The Brown Journal of World Affairs, 17(1), 53-71.

Fukuyama, F. (1995). Social capital and the global economy. Foreign affairs, 89-103.

Harvey, D. (2009). The art of rent: globalisation, monopoly and the commodification of culture. Socialist register, 38(38).

Hill \& Fujita (2003). The nested city: Introduction, Urban Studies, 40 (2) :2007-2017

Krätke, S. (2014). How manufacturing industries connect cities across the world: extending research on 'multiple globalizations'. Global Networks, 14(2), 121-147.

Landis, J., \& Zhang, M. (1998). The second generation of the California urban futures model. Part 1: Model logic and theory. Environment and Planning B: Planning and Design, 25(5), 657-666.

Lever, W. F. (1997). Delinking urban economies: the European experience. Journal of urban affairs, 19(2), 227-238.

Murayama Y. (2000). Japanese urban system, Kluwer Academic Pub., The geojournal Library, $271 \mathrm{p}$.

Meyer D. (1986). The world system of cities: relation between international financial metropolises and South American cities, Social forces, 64(3), pp.553-581

Neal, Z. (2012). Structural determinism in the interlocking world city network. Geographical Analysis, 44(2), 162-170.

OECD (2009). OSLO MANUAL: Guidelines for collecting and interpreting innovation data, OECD/European Communities, http://www.oecd-ilibrary.org

Polese M. (2005). Cities and National Economic Growth: a reappraisal, Urban Studies, 42, 8, 14291451.

Pred A., (1977). City-systems in advanced economies, Hutchinson University Library, London, $256 \mathrm{p}$.

Reichardt, J., Bornholdt, S. (2006). Statistical mechanics of community detection. Physical Review E, 74(1), 016110.

Rossi, U. (2017). Cities in Global Capitalism. John Wiley \& Sons.

Rozenblat C. (2010). Cities networks and competitiveness in Lennert M. ed. FOCI: Future Orientation of Cities in Europe, ESPON report. 
Rozenblat C. (2015). Inter-Cities' Multinational Firms Networks and Gravitation Model, Annals of the Japanese Association of Economic Geographers, 61, 3, 219-23

Rozenblat C., \& Pumain D. (1993). The location of multinational firms in the European urban system.Urban Studies, 10, 1691-1709

Rozenblat C., \& Pumain D., (2007). " Firm linkages, innovation and the evolution of urban systems ». in P.J. Taylor et al (ed.) Cities in Globalization. Practices, policies and theories. Routledge. 130-156

Rozenblat C., Zaidi F., Bellwald A. (2017). The multipolar regionalization of cities in the multinational firms' networks, Global Networks, 17(2), 171-194.

Sassen S. (1991). The Global City : New York, London, Tokyo. Princeton University Press.

Sassen, S. (2007). Sociology of globalization. New York: W.W. Norton.

Sassen S. (2010). Novel spatial formats: Megaregions and gobal cities, in Xu J., Yeh A.O.H eds., Governance and planning of Mega-city regions: An international comparative perspective. UK, Routledge, pp.101-126

Scott, A. J. (2012). A world in emergence: Cities and regions in the 21st century. Edward Elgar Publishing.

Storper, M. (1997). The regional world: territorial development in a global economy. Guilford Press.

Short, J. R., \& Kim, Y. H. (1999). Globalization and the City. Harlow: Longman.

Stark, D. (1996). Recombinant property in East European capitalism. American journal of sociology, 993-1027.

Taylor P.J. (2001). Specification of the World City Network. Geographical analysis, 33 (2), 181-194.

Taylor, P. J., Catalano, G., Walker, D. R. F. (2002). Exploratory Analysis of the World City Network. Urban Studies, 39(13), 2377-2394.

Taylor, P. J., Derudder, B., Hoyler, M., Ni, P. (2013). New regional geographies of the world as practised by leading advanced producer service firms in 2010. Transactions of the Institute of British Geographers, 38(3), 497-511.

UNCTAD, R. (2014). United Nations Conference on Trade and Development. Review of Maritime Transport.

Wall, R. (2009). NETSCAPE: Cities and Global Corporate Networks. PhD. Erasmus University Rotterdam.

Wall, R. S., van der Knaap, G. A. (2011). Sectorial Differentiation and Network Structure Within Contemporary Worldwide Corporate Networks. Economic Geography, 87(3), 267-308.

Walter J., Lechner Chr., Kellermanns Fr.W. (2007). Knowledge transfer between and within alliance partners: private versus collective benefits of social capital. Journal of Business Research, $60,698-710$

Watts, D. J., \& Strogatz, S. H. (1998). Collective dynamics of 'small-world' networks. Nature, 393(6684), 440-442.

Wójcik, D. (2013). Where governance fails: Advanced business services and the offshore world. Progress in Human Geography, 37(3), 330-347. 